\title{
Convenient Synthesis of 3-Vinyl and 3-Styryl Coumarins
}

2011

Vol. 13, No. 19

$5112-5115$

\author{
Joana Gordo, ${ }^{\dagger}$ João Avó, ${ }^{\dagger}$ A. Jorge Parola ${ }^{\dagger}$ João C. Lima, ${ }^{\dagger}$ António Pereira, ${ }^{,, \ddagger}$ and \\ Paula S. Branco*,
}

REQUIMTE, Departamento de Química, Faculdade de Ciências e Tecnologia, FCT, Universidade Nova de Lisboa, Portugal, and Centro de Química, Departamento de Química, Universidade de Évora, Évora, Portugal

psb@dq.fct.unl.pt

Received July 22, 2011

\section{ABSTRACT}

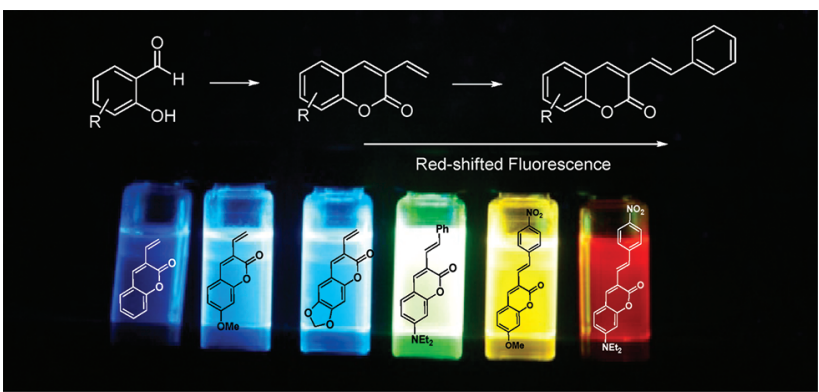

A variety of 2-hydroxy aldehydes on reaction with 3-butenoic acid afford in a one-pot reaction the corresponding 3-vinylcoumarins. As expected, extension of the delocalized $\pi$-electron system accomplished by Heck coupling reactions with aryl halides results in an increased fluorescence of the compounds whose applicability is yet to be established.

Coumarins have been extensively investigated with regard to their outstanding optical properties, and therefore they are a powerful tool for the study of simple molecules in complex biological systems. They are effective fluorophores characterized by high fluorescence quantum yields. ${ }^{1}$ Undeniably they constitute the largest class of fluorescent dyes ${ }^{2}$ and are widely used as emission

${ }^{\dagger}$ Universidade Nova de Lisboa.

$\$$ Universidade de Évora.

(1) Kuznetsova, N. A.; Kaliya, O. L. Usp. Khimii. 1992, 61, 1243.

(2) (a) Jones, G.; Jackson, W. R.; Choi, C.; Bergmark, W. R. J. Phys. Chem. 1985, 89, 294. (b) Koefod, R. S.; Mann, K. R. Inorg. Chem. 1989, 28, 2285. (c) Jagtap, A. R.; Satam, V. S.; Rajule, R. N.; Kanetkar, V. R. Dyes Pigm. 2009, 82, 84.

(3) (a) Lee, M. T.; Yen, C. K.; Yang, W. P.; Chen, H. H.; Liao, C. H.; Tsai, C. H.; Chen, C. H. Org. Lett. 2004, 6, 1241. (b) Swanson, S. A.; Wallraff, G. M.; Chen, J. P.; Zhang, W. J.; Bozano, L. D.; Carter, K. R.; Salem, J. R.; Villa, R.; Scott, J. C. Chem. Mater. 2003, 15, 2305. (c) Chang, C. H.; Cheng, H. C.; Lu, Y. J.; Tien, K. C.; Lin, H. W.; Lin, C. L.; Yang, C. J.; Wu, C. C. Org. Electron. 2010, 11, 247. (d) Yu, T. Z.; Zhang, P.; Zhao, Y. L.; Zhang, H.; Meng, J.; Fan, D. W. Org. Electron. 2009, 10, 653.

(4) (a) Dorlars, A.; Schellhammer, C. W.; Schroeder, J. Angew. Chem., Int. Ed. Engl. 1975, 14, 665. (b) Keskin, S. S.; Aslan, N.; Bayrakceken, N. Spectrochim. Acta, Part A 2009, 72, 254. (c) Kido, J.; Iizumi, Y. Appl. Phys. Lett. 1998, 73, 2721.

(5) (a) Moylan, C. R. J. Phys. Chem. 1994, 98, 13513. (b) Painelli, A.; Terenziani, F. Synth. Met. 2001, 124, 171. layers in organic light-emitting diodes (OLED), ${ }^{3}$ optical brighteners, ${ }^{4}$ nonlinear optical chromophores, ${ }^{5}$ fluorescent whiteners, ${ }^{6}$ and fluorescent labels as well as probes for physiological measurement. ${ }^{7}$ Recently, coumarins have found wide applications in labeling ${ }^{8}$ and caging. ${ }^{9}$ Moreover, compounds of this family likewise show numerous and remarkable biological activity. ${ }^{10}$ Due to their analytical and biological uses, photophysical and spectroscopic properties can be readily modified by the introduction of substituents into the coumarin ring, giving them more flexibility to fit well into various applications, and this is

(6) Wilze, K. A.; Johnson, A. K. Handbook of Detergents, Chemistry, Production, and Application of Fluorescent Whitening Agents, Part F: Production; CRC Press, Taylor \& Francis: Boca Raton, FL, 2007; Chapter 28, p 554.

(7) (a) Kim, J. H.; Kim, H. J.; Kim, S. H.; Lee, J. H.; Do, J. H.; Kim, H. J.; Lee, J. H.; Kim, J. S. Tetrahedron Lett. 2009, 50, 5958. (b) Jung, H. S.; Kwon, P. S.; Lee, J. W.; Kim, J. I.; Hong, C. S.; Kim, J. W.; Yan, S. H.; Lee, J. Y.; Lee, J. H.; Joo, T.; Kim, J. S. J. Am. Chem. Soc. 2009, 131, 2008. (c) Sheng, R. L.; Wang, P. F.; Gao, Y. H.; Wu, Y.; Liu, W. M.; Ma, J. J.; Li, H. P.; Wu, S. K. Org. Lett. 2008, 10, 5015. (d) Kim, H. J.; Park, J. E.; Choi, M. G.; Ahn, S.; Chang, S. K. Dyes Pigm. 2010, 84, 54. (e) Lin, W. Y.; Yuan, L.; Cao, X. W.; Tan, W.; Feng, Y. M. Eur. J. Org. Chem. 2008, 4981.

(8) (a) Goddard, J.-P.; Reymond, J.-L. Trends Biotechnol. 2004, 22, 363. (b) Heiner, S.; Detert, H.; Kuhn, A.; Kunz, H. Bioorg. Med. Chem. 2006, 14, 6149 . 
a study that has assumed great importance in the past decade. ${ }^{11}$ Many articles dealing with their synthesis, reactivity, and spectral profile studies have been published. In particular, it seems that the presence of an aryl or heteroaryl moiety on the 3-position of the coumarinic system induces specific activities. ${ }^{12}$ We have recently reported a particularly useful, easy, and concise synthesis of diversified 3-aryl coumarins using Heck coupling reactions between coumarin and aryl halides. ${ }^{13} \mathrm{~A}$ major issue in expanding the applications of coumarin derivatives is related to their color spectrum and intensity of their spectroscopic bands. One solution arises from increasing the delocalization of the conjugated $\pi$-electron system which will allow us to obtain derivatives of coumarin with absorption bands to longer wavelengths and with greater intensity. One can anticipate that the extension of the $\pi$-delocalized system will lead to compounds showing more promising fluorescent behavior. This would imply a greater challenge, the introduction of an unsaturated fragment between the coumarin ring and the aromatic group attached to the 3-position. This was observed by Bäuerle ${ }^{14}$ and Bochkov ${ }^{15}$ on screening for fluorescent dyes. The introduction of a double bond at the 3-position required for the Heck reaction could be foreseen by (1) formylation of the coumarin ring and (2) olefination by Wittig reaction but was revealed to be impracticable. The first report ${ }^{16}$ on the synthesis of 3-vinylcoumarin was a multistep sequence. A more versatile synthesis of 3-alkenylcoumarins was achieved by a variety of 2-acyl-, 2-aroyl-, and 2-formylsubstituted phenols on reaction with $\alpha, \beta$-unsaturated

(9) (a) Mayer, G.; Heckel, A. Angew. Chem., Int. Ed. 2006, 45, 4900. (b) Geißler, D.; Antonenko, Y. N.; Schmidt, R.; Keller, S.; Krylova, O. O.; Wiesner, B.; Bendig, J.; Pohl, P.; Hagen, V. Angew. Chem., Int. Ed. 2005, 44, 1195. (c) Pinheiro, A. V.; Baptista, P.; Lima, J. C. Nucleic Acids Res. 2008, 36, e90.

(10) (a) Thuong, P. T.; Hung, T. M.; Ngoc, T. M.; Ha, D. T.; Min, B. S.; Kwack, S. J.; Kang, T. S.; Choi, J. S.; Bae, K. Phytother. Res. 2010 , 24, 101. (b) Dayam, R.; Gundla, R.; Al-Mawsawi, L. Q.; Neamati, N. Med. Res. Rev. 2008, 28, 118. (c) Hoult, J. R. S.; Paya, M. Gen. Pharmacol. 1996, 27, 713. (d) Borges, F.; Roleira, F.; Milhazes, N.; Santana, L.; Uriarte, E. Curr. Med. Chem. 2005, 12, 887. (e) Kostova, I. Curr. Med. Chem. Anti-Cancer Agents 2005, 5, 29. (f) Kabeya, L. M.; de Marchi, A. A.; Kanashiro, A.; Lopes, N. P.; da Silva, C.; Pupo, M. T.; Lucisano-Valima, Y. M. Bioorg. Med. Chem. 2007, 15, 1516. (g) Carotti, A.; Altomare, C.; Catto, M.; Gnerre, C.; Summo, L.; De Marco, A.; Rose, S.; Jenner, P.; Testa, B. Chem. Biodiversity 2006, 3, 134. (h) Coumarins: Biology, Applications and Mode of Action; O'Kennedy, R., Thornes, R. D., Eds.; Wiley: Chichester, 1997.

(11) (a) Mizukami, S.; Okada, S.; Kimura, S.; Kikuchi, K. Inorg. Chem. 2009, 48, 7630. (b) Wagner, B. D. Molecules 2009, 14, 210. (c)

Hara, K.; Kurashige, M.; Dan-oh, Y.; Kasada, C.; Shinpo, A.; Suga, S.; Sayama, K.; Arakawa, H. New J. Chem. 2003, 27, 783. (d) Camur, M.; Bulut, M.; Kandaz, M.; Guney, O. Supramol. Chem. 2009, 21, 624.

(12) de Silva, A. P.; Gunaratne, H. Q. N.; Gunnlaugsson, T.; Huxley, A. J. M.; McCoy, C. P.; Rademacher, J. T.; Rice, T. E. Chem. Rev. 1997, 97, 1515 .

(13) Martins, S.; Branco, P. S.; de la Torre, M. C.; Sierra, M. A.; Pereira, A. Synlett 2010, 2918.

(14) (a) Schiedel, M. S.; Briehn, C. A.; Bauerle, P. Angew. Chem., Int. Ed. 2001, 40, 4677. (b) Schiedel, M. S.; Briehn, C. A.; Bauerle, P. J. Organomet. Chem. 2002, 653, 200.

(15) Bochkov, A. Y.; Yarovenko, V. N.; Krayushkin, M. M.; Chibisova, T. A.; Valova, T. M.; Barachevskii, V. A.; Traven, V. F.; Beletskaya, I. P. Russ. J. Org. Chem. 2008, 44, 595.

(16) Minami, T.; Matsumoto, Y.; Nakamura, S.; Koyanagi, S.; Yamaguchi, M. J. Org. Chem. 1992, 57, 167.

(17) Konigs, P.; Neumann, O.; Hackeloer, K.; Kataeva, O.; Waldvogel, S. R. Eur. J. Org. Chem. 2008, 343. carboxylic acid chlorides. ${ }^{17}$ Here we report a more expeditious synthesis of 3-vinyl and 3-styryl coumarin fluorescent dyes from readily available substrates.

When 3-butenoic acid was allowed to react with $N$, $N^{\prime}$-dicyclohexylcarbodiimide (DCC) the corresponding intermediate was then coupled to salicylaldehyde in the presence of $4-N, N^{\prime}$-dimethylaminopyridine (DMAP) to give 2-formylaryl but-3-enoate (1a). ${ }^{18}$

Scheme 1. Synthetic Approach to the Synthesis of 3-Vinyl Coumarins (2) Following a One-Pot Procedure (Pathway A) or through Isolation of Intermediates $\mathbf{1}$ or $\mathbf{3}$ (Pathways B and C)

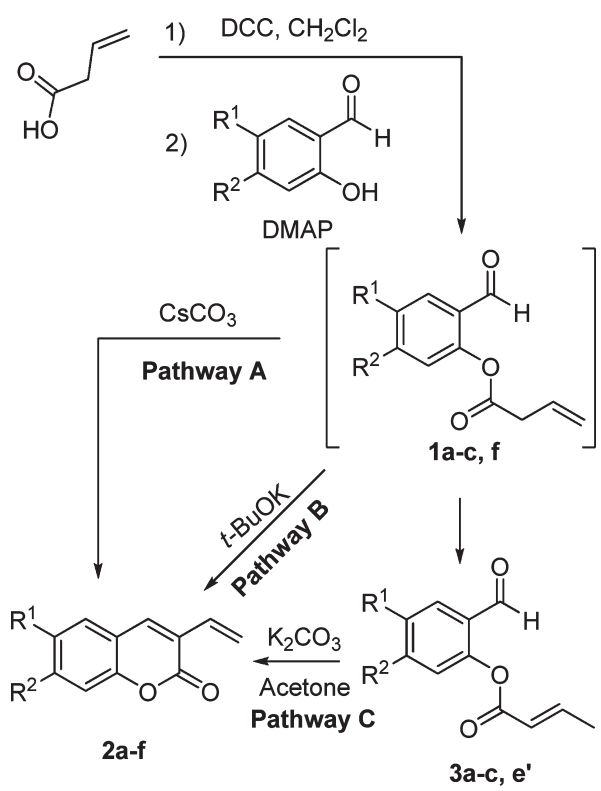

Compound 1a could be converted into the 3-vinyl coumarin $^{16}(\mathbf{2 a})$ in good to moderate yields under treatment with potassium tert-butoxide (Scheme 1, pathway B). However, when treated in situ with cesium carbonate, 1a afforded 2a in a one-pot reaction which allowed us to increase the scale and the yield without suffering isomerization of the double bond (Scheme 1, pathway A). Indeed, when performing the reaction at a larger scale, 1a suffers a predictable rearrangement to compound $\mathbf{3 a}$ as a result of migration of the double bond to a more stable position. $\gamma$-Deprotonation of $\mathbf{3 a}$ was easily accomplished on treatment with potassium carbonate, and 2a was obtained in a satisfying yield (Scheme 1 , pathway C). ${ }^{17}$

Although considered labile intermediates in literature, ${ }^{16}$ we were able to isolate the vinyl coumarins in good yields. Reaction conditions and yields are presented in Table 1. As expected, the one-pot reaction (pathway A) gave better yields of coumarins when compared with other routes that involved isolation of intermediate $\mathbf{1}$ (pathway B) or $\mathbf{3}$ (pathway C). For the synthesis of $\mathbf{2 e}$ we started with 2,4-dihydroxybenzaldehyde and the reagents were doubled

(18) Lazzarato, L.; Donnola, M.; Rolando, B.; Marini, E.; Cena, C.; Coruzzi, G.; Guaita, E.; Morini, G.; Fruttero, R.; Gasco, A.; Biondi, S.; Ongini, E. J. Med. Chem. 2008, 51, 1894. 
Table 1. Yields of 3-Vinyl Coumarins $\mathbf{2}$ and of Intermediates $\mathbf{1}$ and $\mathbf{3}$

\begin{tabular}{|c|c|c|c|c|c|c|c|}
\hline $\mathrm{R}^{1}$ & $\mathrm{R}^{2}$ & 1 , yield $(\%)$ & $\mathbf{3}$, yield $(\%)$ & $\begin{array}{c}3 \text {-vinyl coumarin } \\
\text { yield }(\%)\end{array}$ & pathway A (\%) & pathway B (\%) & pathway $\mathrm{C}(\%)$ \\
\hline $\mathrm{H}$ & $\mathrm{H}$ & 1a, 75 & $\mathbf{3 a}, 42$ & $\mathbf{2 a}$ & 73 & 59 & 63 \\
\hline $\mathrm{H}$ & $\mathrm{OMe}$ & $\mathbf{1 b}, 69$ & $\mathbf{3 b}, 61$ & $\mathbf{2 b}$ & 82 & 85 & 50 \\
\hline $\mathrm{H}$ & $\mathrm{NEt}_{2}$ & 1c, 89 & $3 \mathbf{c}, 47$ & $2 \mathrm{c}$ & 67 & 37 & 72 \\
\hline $\mathrm{H}$ & $\mathrm{OCOPh}$ & & & $\mathbf{2 d}$ & 25 & & \\
\hline $\mathrm{H}$ & $\mathrm{OCOCH}_{2} \mathrm{CH}=\mathrm{CH}_{2}$ & & & $\mathbf{2 e}$ & & 6 & \\
\hline $\mathrm{H}$ & $\mathrm{OCOCH}=\mathrm{CHCH}_{3}$ & & $\mathbf{3} \mathbf{e}^{\prime}, 26$ & $\mathbf{2} \mathbf{e}^{\prime}$ & & 27 & \\
\hline \multicolumn{2}{|c|}{$-\mathrm{OCH}_{2} \mathrm{O}-$} & 1f, 84 & & $2 f$ & 73 & 61 & \\
\hline
\end{tabular}

Table 2. Synthesis of 3-Styryl Coumarins 4 by Palladium Cross-Coupling between 3-Vinyl Coumarins 2 and Aryl Halides ${ }^{a}$
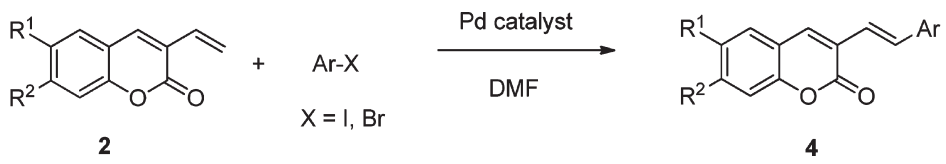

\begin{tabular}{|c|c|c|c|c|c|c|c|c|c|}
\hline entry & compd & $\mathrm{R}^{1}$ & $\mathrm{R}^{2}$ & $\mathrm{Ar}$ & $\begin{array}{c}\text { palladium } \\
\text { catalyst }\end{array}$ & phosphine & $\begin{array}{l}\text { aromatic } \\
\text { halide }\end{array}$ & base & $\begin{array}{c}\text { yield } \\
(\%)\end{array}$ \\
\hline 1 & $4 a$ & $\mathrm{H}$ & $\mathrm{H}$ & $\mathrm{Ph}$ & $\mathrm{Pd}(\mathrm{OAc})_{2}$ & $\mathrm{PPh}_{3}$ & $\mathrm{C}_{6} \mathrm{H}_{5} \mathrm{I}$ & $\mathrm{CH}_{3} \mathrm{CO}_{2} \mathrm{Na}$ & 83 \\
\hline 2 & $4 a$ & $\mathrm{H}$ & $\mathrm{H}$ & $\mathrm{Ph}$ & $\mathrm{Pd}(\mathrm{OAc})_{2}$ & $\mathrm{PPh}_{3}$ & $\mathrm{C}_{6} \mathrm{H}_{5} \mathrm{I}$ & $\mathrm{CsCO}_{3}$ & 41 \\
\hline 3 & $4 \mathbf{a}$ & $\mathrm{H}$ & $\mathrm{H}$ & $\mathrm{Ph}$ & $\mathrm{Pd}(\mathrm{OAc})_{2}$ & $\mathrm{PPh}_{3}$ & $\mathrm{C}_{6} \mathrm{H}_{5} \mathrm{Br}$ & $\mathrm{CH}_{3} \mathrm{CO}_{2} \mathrm{Na}$ & 55 \\
\hline 4 & $4 a$ & $\mathrm{H}$ & $\mathrm{H}$ & $\mathrm{Ph}$ & $\mathrm{Pd}\left(\mathrm{PPh}_{3}\right)_{4}$ & - & $\mathrm{C}_{6} \mathrm{H}_{5} \mathrm{I}$ & $\mathrm{CH}_{3} \mathrm{CO}_{2} \mathrm{Na}$ & 76 \\
\hline 5 & $4 a$ & $\mathrm{H}$ & $\mathrm{H}$ & $\mathrm{Ph}$ & $\mathrm{Pd}\left(\mathrm{PPh}_{3}\right)_{4}$ & - & $\mathrm{C}_{6} \mathrm{H}_{5} \mathrm{I}$ & $\mathrm{CsCO}_{3}$ & 43 \\
\hline 6 & $4 \mathbf{a}$ & $\mathrm{H}$ & $\mathrm{H}$ & $\mathrm{Ph}$ & $\mathrm{Pd}\left(\mathrm{PPh}_{3}\right)_{4}$ & - & $\mathrm{C}_{6} \mathrm{H}_{5} \mathrm{Br}$ & $\mathrm{CH}_{3} \mathrm{CO}_{2} \mathrm{Na}$ & 43 \\
\hline 7 & $4 \mathrm{~b}$ & $\mathrm{H}$ & $\mathrm{OMe}$ & $\mathrm{Ph}$ & $\mathrm{Pd}(\mathrm{OAc})_{2}$ & $\mathrm{PPh}_{3}$ & $\mathrm{C}_{6} \mathrm{H}_{5} \mathrm{I}$ & $\mathrm{CH}_{3} \mathrm{CO}_{2} \mathrm{Na}$ & 98 \\
\hline 8 & $4 b$ & $\mathrm{H}$ & $\mathrm{OMe}$ & $\mathrm{Ph}$ & $\mathrm{Pd}(\mathrm{OAc})_{2}$ & $\mathrm{PPh}_{3}$ & $\mathrm{C}_{6} \mathrm{H}_{5} \mathrm{Br}$ & $\mathrm{CH}_{3} \mathrm{CO}_{2} \mathrm{Na}$ & 35 \\
\hline 9 & $4 c$ & $\mathrm{H}$ & $\mathrm{NEt}_{2}$ & $\mathrm{Ph}$ & $\mathrm{Pd}(\mathrm{OAc})_{2}$ & $\mathrm{PPh}_{3}$ & $\mathrm{C}_{6} \mathrm{H}_{5} \mathrm{I}$ & $\mathrm{CH}_{3} \mathrm{CO}_{2} \mathrm{Na}$ & 56 \\
\hline 10 & $4 c$ & $\mathrm{H}$ & $\mathrm{NEt}_{2}$ & $\mathrm{Ph}$ & $\mathrm{Pd}(\mathrm{OAc})_{2}$ & $\mathrm{PPh}_{3}$ & $\mathrm{C}_{6} \mathrm{H}_{5} \mathrm{Br}$ & $\mathrm{CH}_{3} \mathrm{CO}_{2} \mathrm{Na}$ & 32 \\
\hline 11 & $4 d$ & - & ${ }_{2} \mathrm{O}-$ & $\mathrm{Ph}$ & $\mathrm{Pd}(\mathrm{OAc})_{2}$ & $\mathrm{PPh}_{3}$ & $\mathrm{C}_{6} \mathrm{H}_{5} \mathrm{I}$ & $\mathrm{CH}_{3} \mathrm{CO}_{2} \mathrm{Na}$ & 35 \\
\hline 12 & $4 e$ & $\mathrm{H}$ & $\mathrm{H}$ & $p-\mathrm{NO}_{2}-\mathrm{Ph}$ & $\mathrm{Pd}(\mathrm{OAc})_{2}$ & $\mathrm{PPh}_{3}$ & $\mathrm{BrC}_{6} \mathrm{H}_{4} \mathrm{NO}_{2}$ & $\mathrm{CH}_{3} \mathrm{CO}_{2} \mathrm{Na}$ & 83 \\
\hline 13 & $4 f$ & $\mathrm{H}$ & $\mathrm{OMe}$ & $p-\mathrm{NO}_{2}-\mathrm{Ph}$ & $\mathrm{Pd}(\mathrm{OAc})_{2}$ & $\mathrm{PPh}_{3}$ & $\mathrm{BrC}_{6} \mathrm{H}_{4} \mathrm{NO}_{2}$ & $\mathrm{CH}_{3} \mathrm{CO}_{2} \mathrm{Na}$ & 13 \\
\hline 14 & $4 g$ & $\mathrm{H}$ & $\mathrm{NEt}_{2}$ & $p-\mathrm{NO}_{2}-\mathrm{Ph}$ & $\mathrm{Pd}(\mathrm{OAc})_{2}$ & $\mathrm{PPh}_{3}$ & $\mathrm{BrC}_{6} \mathrm{H}_{4} \mathrm{NO}_{2}$ & $\mathrm{CH}_{3} \mathrm{CO}_{2} \mathrm{Na}$ & 9 \\
\hline 15 & $4 \mathrm{~h}$ & $\mathrm{H}$ & $\mathrm{OMe}$ & 1-naphthyl & $\mathrm{Pd}(\mathrm{OAc})_{2}$ & $\mathrm{PPh}_{3}$ & 1-Br-naphthalen & $\mathrm{CH}_{3} \mathrm{CO}_{2} \mathrm{Na}$ & 47 \\
\hline
\end{tabular}

${ }^{a}$ Reaction conditions: to a solution of 3-vinylcoumarin $\left(40 \mathrm{mg}, 0.23 \mathrm{mmol}, 1\right.$ equiv) in DMF $(3 \mathrm{~mL})$ at $80{ }^{\circ} \mathrm{C}$ were added the palladium acetate (10.4 mg, $0.046 \mathrm{mmol}, 0.2$ equiv), base ( $0.26 \mathrm{mmol}, 1.1$ equiv), triphenylphosphine ( $48 \mathrm{mg}, 0.186 \mathrm{mmol}, 0.8$ equiv), and aryl halide ( $28 \mathrm{mmol}, 1.2 \mathrm{equiv}$ ).

due to the two acylating positions. The yield of compound $\mathbf{2} \mathbf{e}$ is very low due to the fact that compounds $\mathbf{1 e}$ and $\mathbf{3} \mathbf{e}^{\prime}$ can be formed owing to the isomerization of the double bond. As a consequence, isomer $\mathbf{2} \mathbf{e}^{\prime}(27 \%)$ actually predominates over $2 \mathrm{e}(6 \%)$. The extension of the $\pi$-electron system was simply achieved using the Heck palladium cross-coupling reactions between aryl iodides or bromides and the 3-vinyl coumarins previously synthesized. By varying $\mathrm{R}^{2}$ or/and $\mathrm{R}^{3}$ (Table 2) a structural diversity of compounds could be synthesized by a straightforward method.

As expected, iodo halides gave better yields than bromo halides (Table 2, entry 1 vs 3,7 vs 8 , and 9 vs 10) which reflects the stronger polarization of the $\mathrm{C}-\mathrm{I}$ bond in relation to $\mathrm{C}-\mathrm{Br}$. The presence of a $p$-nitro group on the aryl halide makes the covalent bond between the aryl moiety and the bromine stronger. As a result there is a decrease in the yield (Table 2 , entry 8 vs 13 and 10 vs 14). Changing the reaction conditions (catalyst, base, temperature) revealed that the system coumarin (1.0 equiv)/ $\mathrm{PhI}$ (1.2 equiv)/ $\mathrm{Pd}(\mathrm{OAc})_{2}\left(0.2\right.$ equiv) $/ \mathrm{PPh}_{3}\left(0.8\right.$ equiv) $/ \mathrm{CH}_{3} \mathrm{CO}_{2} \mathrm{Na}(1.1$ equiv) $/ \mathrm{DMF} / 80{ }^{\circ} \mathrm{C}$ was the most efficient to furnish the desired 3-styryl coumarin.

The fluorescence of coumarins is strongly dependent on the electron-donating or -withdrawing ability of the substituents. Absorption and emission properties of the synthesized coumarins as well as fluorescence quantum yields $\left(\Phi_{\mathrm{F}}\right)$ and average fluorescence decay lifetimes $\left(\tau_{\mathrm{m}}\right)$ are summarized in Table 3 (more details in Supporting Information). Absorption maxima reveal that the more conjugated styryl derivatives are all red-shifted when compared with the respective vinyl derivatives. It is also clear, in both the vinyl and styryl families, that introduction of 
Table 3. Absorption and Emission Maxima, Fluorescence Quantum Yield and Average Fluorescent Lifetime of Selected Coumarins in Acetonitrile Solutions

\begin{tabular}{|c|c|c|c|c|c|c|c|c|}
\hline compd & $\mathrm{R}^{1}$ & $\mathrm{R}^{2}$ & $\mathrm{Ar}$ & $\lambda_{\mathrm{abs}}{ }^{a}[\mathrm{~nm}]$ & $\varepsilon^{b}\left[\mathrm{~cm}^{-1} \mathrm{M}^{-1}\right]$ & $\lambda_{\mathrm{em}}{ }^{a}[\mathrm{~nm}]$ & $\phi_{\mathrm{F}}^{c}$ & $\tau_{\mathrm{m}}^{d}[\mathrm{~ns}]$ \\
\hline $\mathbf{2 a}$ & $\mathrm{H}$ & $\mathrm{H}$ & - & 326 & 23535 & 413 & 0.08 & 0.39 \\
\hline $2 \mathbf{b}$ & $\mathrm{H}$ & $\mathrm{OMe}$ & - & 333 & 27607 & 425 & 0.99 & 2.84 \\
\hline 2c & $\mathrm{H}$ & $\mathrm{NEt}_{2}$ & - & 400 & 33212 & 470 & 0.98 & 2.84 \\
\hline 2d & $\mathrm{H}$ & $\mathrm{OCOPh}$ & - & 328 & 25044 & 420 & 0.23 & 3.28 \\
\hline $2 \mathbf{e}$ & $\mathrm{H}$ & $\mathrm{OCOCH}_{2} \mathrm{CH}=\mathrm{CH}_{2}$ & - & 320 & 23143 & 430 & 0.19 & 2.81 \\
\hline $2 f$ & \multicolumn{2}{|c|}{$-\mathrm{OCH}_{2} \mathrm{O}-$} & - & 363 & 14504 & 448 & 0.65 & 3.68 \\
\hline $4 a$ & $\mathrm{H}$ & $\mathrm{H}$ & $\mathrm{H}$ & 351 & 27618 & 440 & 0.61 & 2.48 \\
\hline $4 b$ & $\mathrm{H}$ & $\mathrm{OMe}$ & $\mathrm{H}$ & 366 & 27860 & 464 & 0.71 & 2.75 \\
\hline $4 c$ & $\mathrm{H}$ & $\mathrm{NEt}_{2}$ & $\mathrm{H}$ & 421 & 24682 & 477 & 0.85 & 2.25 \\
\hline $4 d$ & \multicolumn{2}{|c|}{$-\mathrm{OCH}_{2} \mathrm{O}-$} & $\mathrm{H}$ & 369 & 18408 & 469 & 0.53 & 2.95 \\
\hline $4 e$ & $\mathrm{H}$ & $\mathrm{H}$ & $\mathrm{NO}_{2}$ & 371 & 40311 & 539 & 0.04 & 0.08 \\
\hline $4 f$ & $\mathrm{H}$ & $\mathrm{OMe}$ & $\mathrm{NO}_{2}$ & 392 & 46130 & 610 & 0.24 & 1.23 \\
\hline $4 g$ & $\mathrm{H}$ & $\mathrm{NEt}_{2}$ & $\mathrm{NO}_{2}$ & 459 & 57040 & $>800$ & $<0.01$ & $<0.04$ \\
\hline
\end{tabular}

${ }^{a}$ Absorption maxima in acetonitrile (longest wavelength transition). ${ }^{b}$ Molar decadic extinction coefficient at longest wavelength transition. ${ }^{c}$ Quantum yield measured with an integrating sphere. ${ }^{19}{ }^{d}$ Fluorescence lifetime was determined by single photon counting technique. Decays were deconvoluted from the excitation pulse using Striker's Sand program. ${ }^{20}$

electron donor groups to position 7 and/or electron-withdrawing groups to position 3 lead to red-shifted maxima corresponding to more conjugated systems with stronger charge transfer character. A comparative analysis of the values in Table 3 reveals that the nature of the substituent in the coumarin core affects the fluorescence of these compounds. Based on substitution at position 3 of the benzopyrone ring, these compounds can be divided into two series, one bearing a vinyl substituent at position 3, and the other, with a more extended $\pi$ system, bearing a styryl group. Except for the nonsubstituted compounds (2a and 4a) all of the styryl coumarins exhibit a lower fluorescence quantum yield than their vinyl counterparts. These results are corroborated by measuring the fluorescence decay times of these compounds, with the 3-styryl derivatives having slightly shorter average decay times than the 3-vinyl derivatives. These data suggest that the introduction of an extra phenyl group in the system opens a new nonradiative deactivation pathway. Cis-trans isomerization is a reasonable hypothesis, and it is supported by previous reports. ${ }^{15,21}$ The unpredictably low fluorescence quantum yield of $\mathbf{2 a}$, which cannot undergo cis-trans isomerization, can be explained by its high photoreactivity $\left(\phi \approx 0.20\right.$ at $\lambda_{\text {irr }}=313 \mathrm{~nm}$; see Supporting Information). This behavior is not exhibited by any of the

(19) (a) Chekalyuk, A.; Fadeev, V.; Georgiev, G.; Kalkanjiev, T.; Nickolov, Z. Spectrosc. Lett. 1982, 15, 355. (b) Ware, W. R.; Rothman, W. Chem. Phys. Lett. 1976, 39, 449.

(20) Striker, G.; Subramaniam, V.; Seidel, C. A. M.; Volkmer, A. J. Phys. Chem. B 1999, 103, 8612.

(21) Moorthy, J. N.; Venkatakrishnan, P.; Savitha, G.; Weiss, R. G. Photochem. Photobiol. Sci. 2006, 5, 903. other 3-vinyl coumarin derivatives, suggesting that the addition of an electron-donating or -withdrawing group at position 7, as well as the presence of a styryl group at position 3, deactivates this photoreaction. Furthermore, the introduction of a $p$-nitro group in the 3-styryl moiety leads to considerable changes in the fluorescence properties of coumarin derivatives $(\mathbf{4 e}, \mathbf{4 f}, \mathbf{4 g})$. In the case of coumarin $4 \mathrm{~g}, \Phi_{\mathrm{F}}$ and $\tau_{\mathrm{m}}$ are especially low and short, respectively, and the emission maximum occurs above $800 \mathrm{~nm}$ (above our instrumental resolution), due to the charge transfer coupling between the electron-donating $\mathrm{NEt}_{2}$ group and electron-withdrawing $\mathrm{NO}_{2}$ group. ${ }^{22}$

With the objective to increase the delocalization of the $\pi$-electron system, new vinyl and styryl coumarin derivatives with potential applications, such as fluorescent chemosensors, were developed by a simple and efficient synthetic strategy involving two simple steps. Applicability is yet to be established.

Acknowledgment. We thank Fundação para a Ciência e Tecnologia (Portugal) for partial financial support through the FCOMP-01-0124-FEDER-007448 project and PhD Grant SFRH/BD/65127/2009 (J.A.).

Supporting Information Available. General experimental procedure, spectral data and characterization data for new compounds, absorption and emission spectra, and fluorescence decays. This material is available free of charge via the Internet at http://pubs.acs.org.

(22) (a) Suresh, M.; Das, A. Tetrahedron Lett. 2009, 50, 5808. (b) Valeur, B.; Leray, I. Coord. Chem. Rev. 2000, 205, 3. 